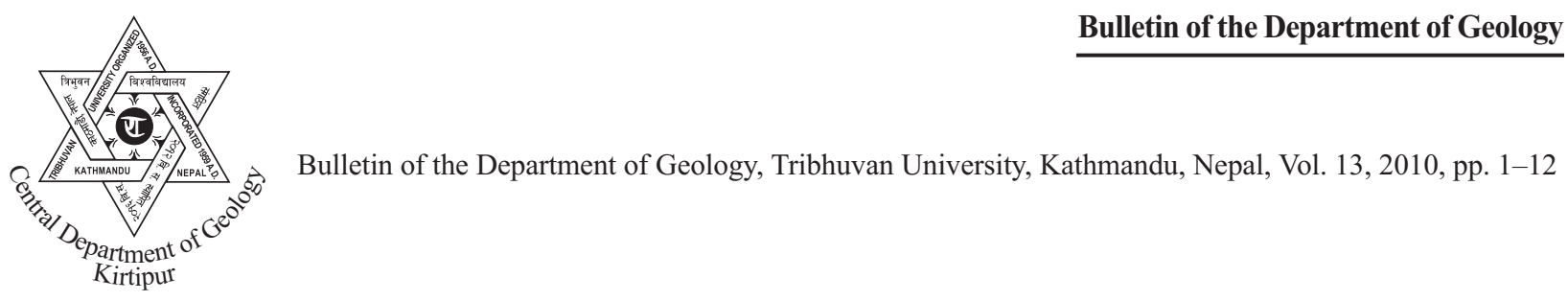

\title{
Morpho-hydraulic parameters and existing stability condition of Nakhu River, southern Kathmandu, Central Nepal
}

\author{
Binod Maharjan and *Naresh Kazi Tamrakar \\ Central Department of Geology, Tribhuvan University, Kathmandu, Nepal
}

\begin{abstract}
The Nakhu River is the fifth order main stem which contributes the Bagmati River from the southern part of the Kathmandu valley. Based on morphologic and hydraulic assessments, the river segments 1, 2 and 3 (fifth order streams), and Segment 4 (fourth order stream) were classified respectively as C5-, C5-, C4- and C4-streams. C5-streams were sandy meandering streams and C4 streams are gravelly meandering streams. All these segments were moderately entrenched with relatively low bank height ratios except for Segment 3. These stream segments were laterally unstable and are competent enough to mobilise their riverbed materials. Currently all the segments are potentially aggrading depending on F-M relationship. However, the relationship may be impaired by human activities. To improve the river further studies and rehabilitation works are required.
\end{abstract}

\section{INTRODUCTION}

The Nakhu watershed lies between latitude $27^{\circ} 32^{\prime} 15^{\prime \prime} \mathrm{N}$ to $27^{\circ} 40^{\prime} 40^{\prime \prime} \mathrm{N}$ and longitude $85^{\circ} 17^{\prime} 10^{\prime \prime} \mathrm{E}$ to $85^{\circ} 24^{\prime} 30^{\prime \prime} \mathrm{E}$ (Fig. 1). It extends for about $16 \mathrm{~km} \mathrm{~N}-\mathrm{S}$ and about $12 \mathrm{~km} \mathrm{E-W}$, and has an area of about $58 \mathrm{~km}^{2}$ with an altitude ranging from $1260 \mathrm{~m}$ to $2625 \mathrm{~m}$ above mean sea level. The watershed is demarcated by the Mahabharat Range in the southern part, while by the Quaternary terrace deposits of valley sediments in the other parts. In the southern part the watershed is surrounded by Phulbaridada in east $(2590 \mathrm{~m})$, Gothdada in south $(2083 \mathrm{~m})$ and Deurali in west $(2075 \mathrm{~m})$.

The Nakhu River is one of the largest rivers contributing to the Bagmati River from the southern ranges of the Kathmandu valley. These ranges have been actively uplifting from last $1 \mathrm{Ma}$ (Sakai, 2001). Hence huge amount of sediments have been carried and transported by the Nakhu River from the uplifting and eroded southern ranges, and the materials have been deposited in the form of gravelly to sandy

\footnotetext{
*Corresponding author:

E-mail address: ntamrakar@hotmail.com
}

terrace deposits. These deposits exist at elevated horizons and the Nakhu River has incised the valley further depositing at successively lower levels of terraces and currently the sediments have been deposited at the recent flood plains. From the geomorphological point of view the river has remained quite active and experienced several debris flow events at past, and the whole watershed area contributed as alluvial fans to the peripheral part of the paleo Kathmandu lake. Our focus is on the current and future activity of the Nakhu River and we are mainly concerned on the river covering hydrologic flood plans. Recently the Nakhu River has been very much disturbed by various anthropogenic factors, which have altered and impaired stability condition and function of the river. Therefore, the objectives of this study are (a) firstly to recognise morphology, geometry, and type, and (b) secondly, to evaluate the stability condition (aggrading/degrading potential, and how competent the river is). Tamrakar (2004), Shrestha and Tamrakar (2007), Tamrakar and Bajracharya (2009) evaluated stability condition of the Bishnumati and the Manahara Rivers, the major tributaries of the Bagmati 


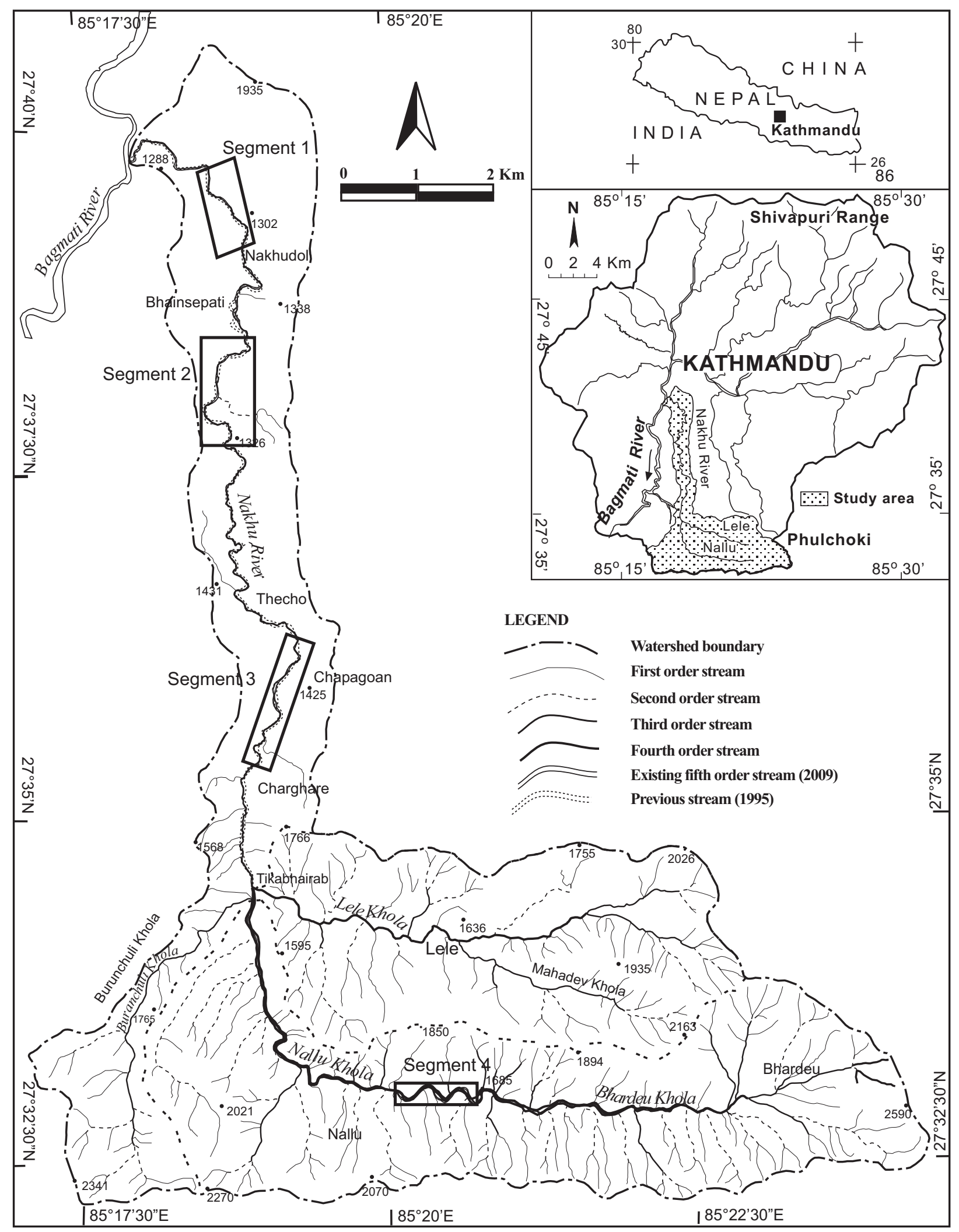

Fig. 1 Location map, drainage order and four surveyed segments of the Nakhu River 
River originating from the northern ranges. The present study sets up the stability condition of the one of the major rivers originating from the southern ranges of Kathmandu.

\section{METHODOLOGY}

The regional watershed parameters and river planiform were measured from the topo maps (1:10,000 and 1:25,000) and reconnaissance field visit was made along the river. Then four representative segments of the Nakhu River were selected (Fig. 1) based on their planiform, and nature of channel condition, as segment 1 (Nakhu area), Segment 2 (Bhainsepati area), Segment 3 (Chapagaon area), and Segment 4 (Nallu area). These segments were surveyed for cross-sectional and longitudinal profiles using a leveling instrument, staff and a measuring tape. For the characterisation of grain size in segment, Wolman's (1954) pebble counting method was applied in each transects of the four segments. The median grain size obtained from segment counting was applied in stream classification after Rosgen (1994). The volumetric bar surface samples were sieved separately for grain size parameter and stream competence evaluation. The stream segments were classified according to the criteria of Rosgen (1994). Because there is no discharge measuring station, bankfull discharge and velocity were deduced using Manning's equation and continuity equation. The Manning's roughness coefficients were evaluated from the field survey of stream segments. Stream aggrading/degrading potential was evaluated using $\mathrm{F}$ versus $\mathrm{M}$ relationship of Schumm (1963).

\section{MORPHOMETRY}

The Nakhu River originates from Phulbaridada of the Phulchoki Range located at the SE of the watershed, where the river originates as the Bhardeu Khola, which transfers to the Nallu Khola at Nallu village. The Nallu Khola after contribution from the Lele Khola at Tikabhairav becomes the main stem Nakhu River.

\section{Drainage order}

The drainage order of the Nakhu watershed ranges from first order to fifth order (Fig. 1). The fifth order stream has greater length extending for about $14 \mathrm{~km}$. The first, second, third, and fourth order streams extend for $1.19 \mathrm{~km}, 0.89 \mathrm{~km}$, and 0.59 $\mathrm{km}, 9.31 \mathrm{~km}$, which is measured along the main stem, respectively.

The Nakhu River is a fifth order river fed by two 4th order and one 3rd order major tributaries with three sub-basins viz Nallu Khola, Lele Khola, and Burunchuli Khola. Among these sub-basin, the Nallu Khola sub-basin is the largest of about 22.64 $\mathrm{km}^{2}$, the Lele Khola sub-basin with $14.922 \mathrm{~km}^{2}$ and the Burunchuli Khola sub-basin is the smallest of about $4.457 \mathrm{~km}^{2}$.

\section{Drainage pattern}

In the Nakhu watershed, there are mainly two kinds of drainage patterns viz dendritic and parallel. The southern part of the watershed exhibits parallel drainage pattern. The dendritic drainage pattern is observed in the hills of Bhardeu, Lele, and Burunchuli.

\section{Drainage texture}

The drainage texture of the Nakhu watershed is fine to moderate at the southern part where bed rocks exist, whereas it is coarse to very coarse at the central and the northern parts of the watershed, which is relatively low-lying terrace fields (Fig. 2a).

\section{Relative relief}

The southern part of watershed, which is surrounded by hills, has a low relative relief (Fig. $2 b)$. The northern part, which is a low lying area, has a low relative relief. The higher relief in the southern part is attributed to active erosion, upliftment of the ridges, and presence of competent rocks.

\section{LANDUSE}

Most of the floodplains, the low-lying land and the gentle slope area are used for farming and settlement. The other parts are covered by forest, and some of the parts as quarry sites for construction materials. Most of the southern parts of watershed consist of steep to gentle slopes, which are covered by forest. Also most of the quarries in the area are located in these hills of southeastern to southwestern part of the watershed. Increase in sediment load from quarry sites causes increase in turbidity of river 
which inturn causes reduction in aquatic life. Other problem, which is an uncontrolled quarrying, might generate temporary damming of river due to high sediment discharge in river from quarry during a heavy rainfall.

North of the Tikabhairab Gorge, landuse is mostly farm land. But with demand for settlement for growing population, the landuse pattern has changed rapidly in the watershed. Most of the huge floodplains of the Nakhu River from downstream of Bhaisepati (confluence with the Bagmati River) that is used for agriculture have changed rapidly to build-up area, farm land and industrial area. Because of these, the banks of Nakhu River have been suffering from human encroachment. The water quality has also been highly degraded due to contamination of sewer and solid waste.

\section{GEOLOGY}

The Nakhu watershed comprises of

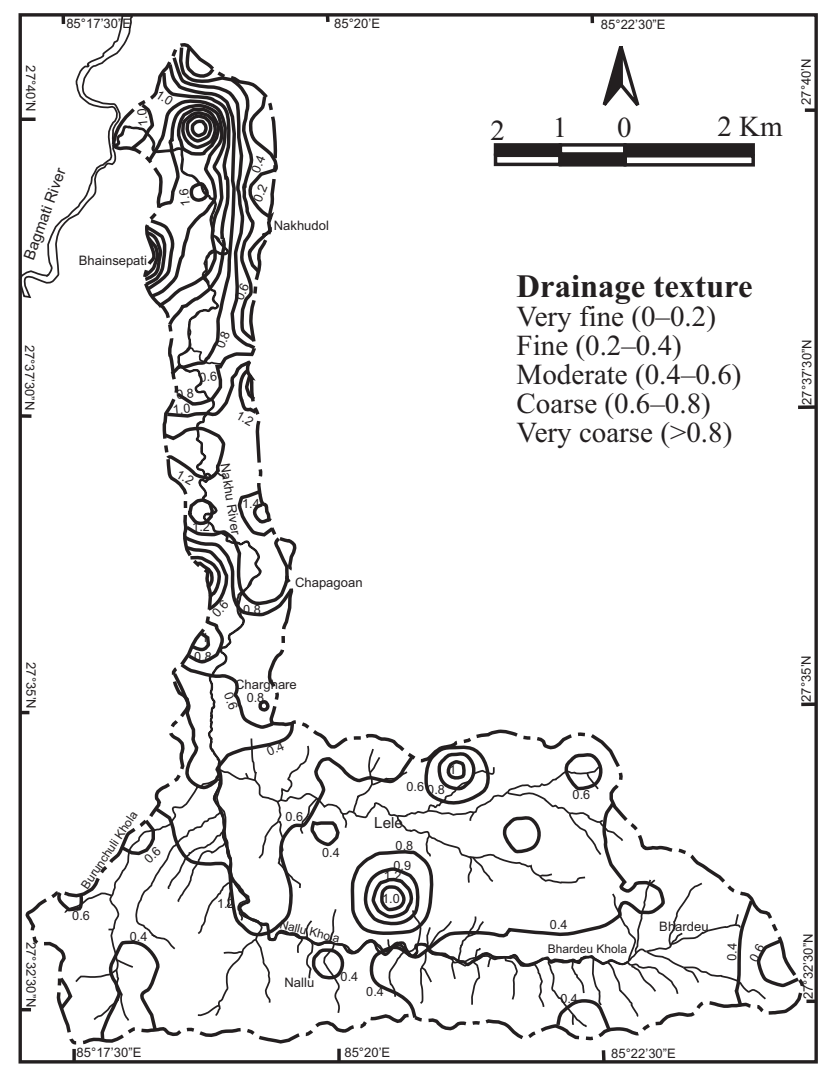

(a) metasedimentary rocks of the Phulchoki Group and the soft sediments of the Kathmandu valley. The Nakhu River originates from the Chandragiri Limestone and traverses over the basin-fill sediments of Bhardeu in the south east. Some tributaries also originate and flow across the rocks of the Tistung and the Sopyang Formations in the south, and the basinfill sediments at the north of watershed.

At southern part of the Nakhu watershed, a thick sequence of the Tistung Formation crops out on both banks of the Nallu Khola. A vertical fault trending NW-SE and a few lineaments were also reported from the Nallu Khola area (Stöcklin and Bhattarai, 1977). The Tistung Formation consists of metasandstones, metasiltstones and phyllites. The Sopyang Formation lying between the Tistung Formation and the Chandragiri Limestone has a transitional zone with a mixed lithology of both. At the Tikabhairav gorge, the Nakhu River flows through the thick sequence of the Chandragiri Limestone with the main rock type of yellow to brown weathered

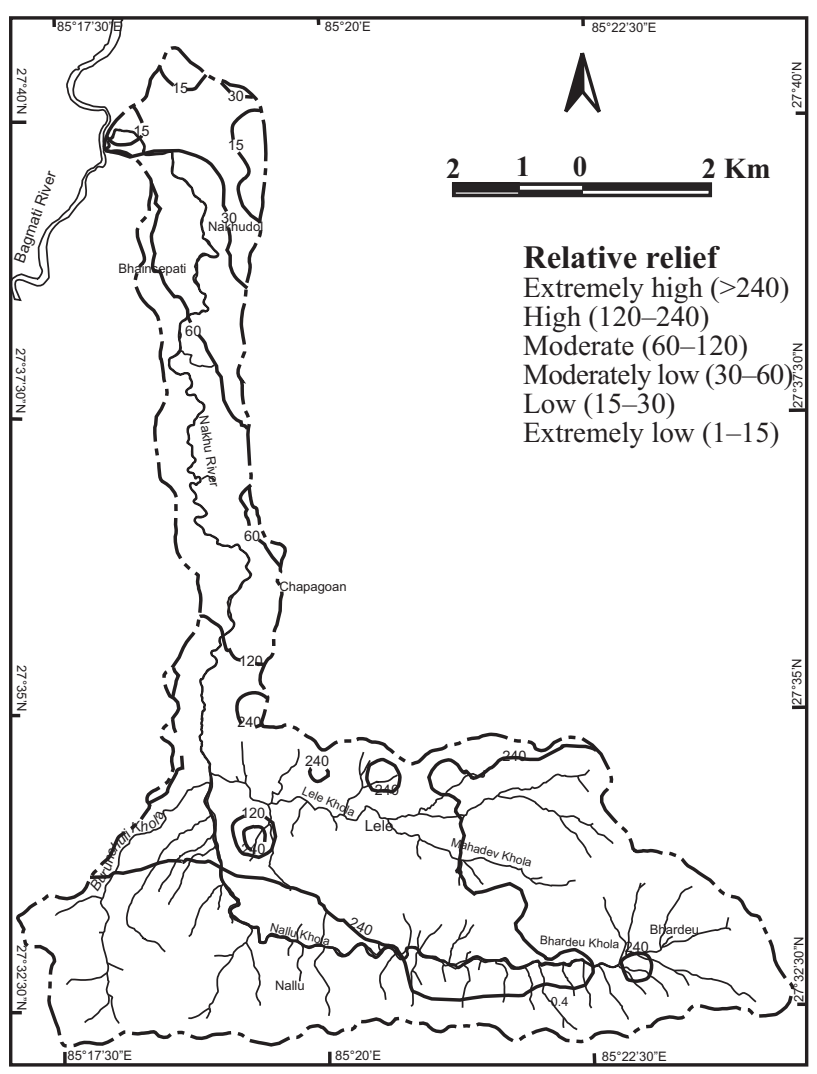

(b)

Fig. 2 (a) Drainage Texture Map and (b) Relative Relief Map of the Nakhu watershed (In both figures the first order streams are not shown for clarity of the figure) 
limestone. The latter appears massive from a distance but is always well bedded and is quite platy at close view (Stocklin, 1981). The fluvio lacurtrine deposit covers the central \& northern part of the watershed. The Lukundol and Kalimati Formations are finegrained deposits exposed mainly in the central and the northern parts of the watershed at low-lying areas. The Chapagoan Formation is the Holocene alluvial fan deposit (DMG ,1998), which is distributed in the central part at the higher levels compared to fine-grained deposits. It is characterized by cobble pebble gravel composed of metasandstone, metasiltstone, phyllite, shale, and limestone clasts.

\section{MORPHOLOGIC PARAMETERS}

\section{Planiform Geometry}

The results of planiform geometry are listed in Table 1 . The sinuosity (K) of Segment 2 exceeds 1.4 whereas other segments have values below it. Segments 1, 3 and 4 are low sinuosity river segments, and Segment 2 is somewhat sinuous river segment.

Table 1: LPlaniform and hydraulic parameters of the Nakhu River

\begin{tabular}{|c|c|c|c|c|}
\hline Attribute & Segment 1 & Segment 2 & Segment 3 & Segment 4 \\
\hline \multicolumn{5}{|l|}{ Pattern } \\
\hline Length of channel thalweg, $\mathrm{L}_{\mathrm{tw}}(\mathrm{m})$ & 1510.90 & 2605.00 & 1792.24 & 1570.00 \\
\hline Length of valley, $\mathrm{L}_{\text {valley }}(\mathrm{m})$ & 1290.00 & 1708.88 & 1500.48 & 1260.00 \\
\hline Sinuosity, $\mathrm{K}=\mathrm{L}_{\mathrm{tw}} / \mathrm{L}_{\text {valley }}(\mathrm{m} / \mathrm{m})$ & 1.17 & 1.52 & 1.19 & 1.25 \\
\hline Meander length, $\mathrm{L}_{\mathrm{m}}(\mathrm{m})$ & 607.30 & 574.84 & 460.22 & 400.00 \\
\hline Belt width, $\mathrm{W}_{\text {blt }}(\mathrm{m})$ & 263.11 & 356.36 & 255.29 & 211.43 \\
\hline Radius of curvature, $\mathrm{R}_{\mathrm{c}}(\mathrm{m})$ & 177.62 & 201.94 & 137.53 & 107.09 \\
\hline Mander length ratio, $\mathrm{L}_{\mathrm{m}} / \mathrm{W}_{\mathrm{bkf}}$ & 34.43 & 32.26 & 18.05 & 31.05 \\
\hline Meander width ratio, $\mathrm{W}_{\mathrm{blt}} / \mathrm{W}_{\mathrm{bkf}}$ & 14.92 & 20.00 & 25.50 & 16.41 \\
\hline \multicolumn{5}{|l|}{ Riffle Cros-section } \\
\hline Width at bankfull, $\mathrm{W}_{\mathrm{bkf}}(\mathrm{m})$ & 17.64 & 17.82 & 19.53 & 12.88 \\
\hline Bankfull x-section area, $A_{b k f}\left(m^{2}\right)$ & 11.62 & 8.39 & 9.20 & 5.82 \\
\hline Max depth at bankfull, $\mathrm{D}_{\max }(\mathrm{m})$ & 1.00 & 0.77 & 0.77 & 0.72 \\
\hline Flood prone height, $\mathrm{D}_{\mathrm{fph}}(\mathrm{m})$ & 2.00 & 1.53 & 1.53 & 1.44 \\
\hline Width flood prone area, $\mathrm{W}_{\mathrm{fpa}}(\mathrm{m})$ & 57.52 & 72.12 & 51.83 & 36.92 \\
\hline Max depth top low bank, $\mathrm{D}_{\text {tob }}(\mathrm{m})$ & 2.44 & 1.81 & 4.24 & 1.98 \\
\hline Mean depth at bankfull, $\mathrm{D}_{\mathrm{bkf}}=\mathrm{A}_{\mathrm{bkf}} / \mathrm{W}_{\mathrm{bkf}}(\mathrm{m})$ & 0.62 & 0.44 & 0.40 & 0.42 \\
\hline Entrenchment ratio, $\mathrm{ER}=\mathrm{W}_{\mathrm{fpa}} / \mathrm{W}_{\mathrm{bkf}}$ & 3.05 & 4.00 & 2.87 & 3.37 \\
\hline Width depth ratio, $\mathrm{W} / \mathrm{D}=\mathrm{W}_{\mathrm{bkf}} / \mathrm{D}_{\mathrm{bkf}}$ & 30.19 & 39.94 & 49.06 & 31.26 \\
\hline Bank height ratio, $\mathrm{BHR}=\mathrm{D}_{\text {tob }} / \mathrm{D}_{\max }$ & 2.62 & 2.52 & 5.28 & 2.79 \\
\hline Max depth ratio, $\mathrm{D}_{\max } / \mathrm{D}_{\mathrm{bkf}}$ & 1.68 & 1.70 & 1.85 & 1.75 \\
\hline \multicolumn{5}{|l|}{ Pool cross-section } \\
\hline Pool width, $\mathrm{W}_{\text {pool }}(\mathrm{m})$ & 11.86 & 12.48 & 13.38 & 10.03 \\
\hline Pool area, $A_{\text {pool }}\left(\mathrm{m}^{2}\right)$ & 5.51 & 4.25 & 5.92 & 5.78 \\
\hline Pool max depth, $\mathrm{D}_{\text {pool }}(\mathrm{m})$ & 0.85 & 0.70 & 0.91 & 0.91 \\
\hline Slope of Channel, $\mathrm{S}_{\text {average }}=\Delta \mathrm{Elv} . / \Delta \mathrm{L}_{\mathrm{tw}}(\mathrm{m} / \mathrm{m})$ & 0.012 & 0.013 & 0.015 & 0.017 \\
\hline
\end{tabular}


Segment 1 and 2 have relatively large meander length $\left(\mathrm{L}_{\mathrm{m}}\right)$ compared to other two segments. Segment 2 exhibits the largest radius of curvature $\left(\mathrm{R}_{\mathrm{c}}\right)$ and segment 4 has the smallest radius of curvature $\left(\mathrm{R}_{\mathrm{c}}\right)$. Segment 2 has high meander belt width $\left(\mathrm{W}_{\mathrm{blt}}\right)$ compared to other segments. Therefore, Segment 2 is potential to lateral accretion, whereas Segments 3 and 4 have nearly same magnitude of meander length and meander belt width.

Riffle and pool cross-sectional areas range from 5.81 to $11.62 \mathrm{~m}^{2}$ and from 4.24 to $5.9 \mathrm{~m}^{2}$, respectively (Table 1). The width $\left(\mathrm{W}_{\mathrm{bkf}}\right)$ is highest in Segment 3 , with value $19.53 \mathrm{~m}$ and is lowest $(5.8 \mathrm{~m})$ in Segment 4. Segment 1 has the greatest maximum depth $(1 \mathrm{~m})$ and the mean depth $(0.62 \mathrm{~m})$, Segment 4 has the least maximum depth $(0.72 \mathrm{~m})$ and the mean depth $(0.42 \mathrm{~m})$. Segments 2,3 and 4 have almost similar bankfull depth. The floodprone width of Segment 2 is the highest $(72 \mathrm{~m})$ and Segment 4 is the least $(36 \mathrm{~m})$. The cross-sectional area and width increase from Segment 4 to Segment 3, and decrease slightly in Segment 2, and are greatest in Segment 1 with slightly narrow channel with maximum depth.

The entrenchment ratios (ER) in all the four segments have nearly same value and all segments are moderately entrenched. Segment 2 has the greatest ER (4) showing greater affinity towards flooding than other segments.

W/D ratio is in the range of 30 to 40 for segments 1, 2 and 4. Segment 3 has almost twice the W/D ratio (75.66) compared to other segments. Segment 3 also has the greatest bank height ratio (BHR) of 5.28. The downstream segments possess comparatively low value of BHR and are vulnerable to lateral shifting of river and flooding.

The meander length ratio (MLR) varies from
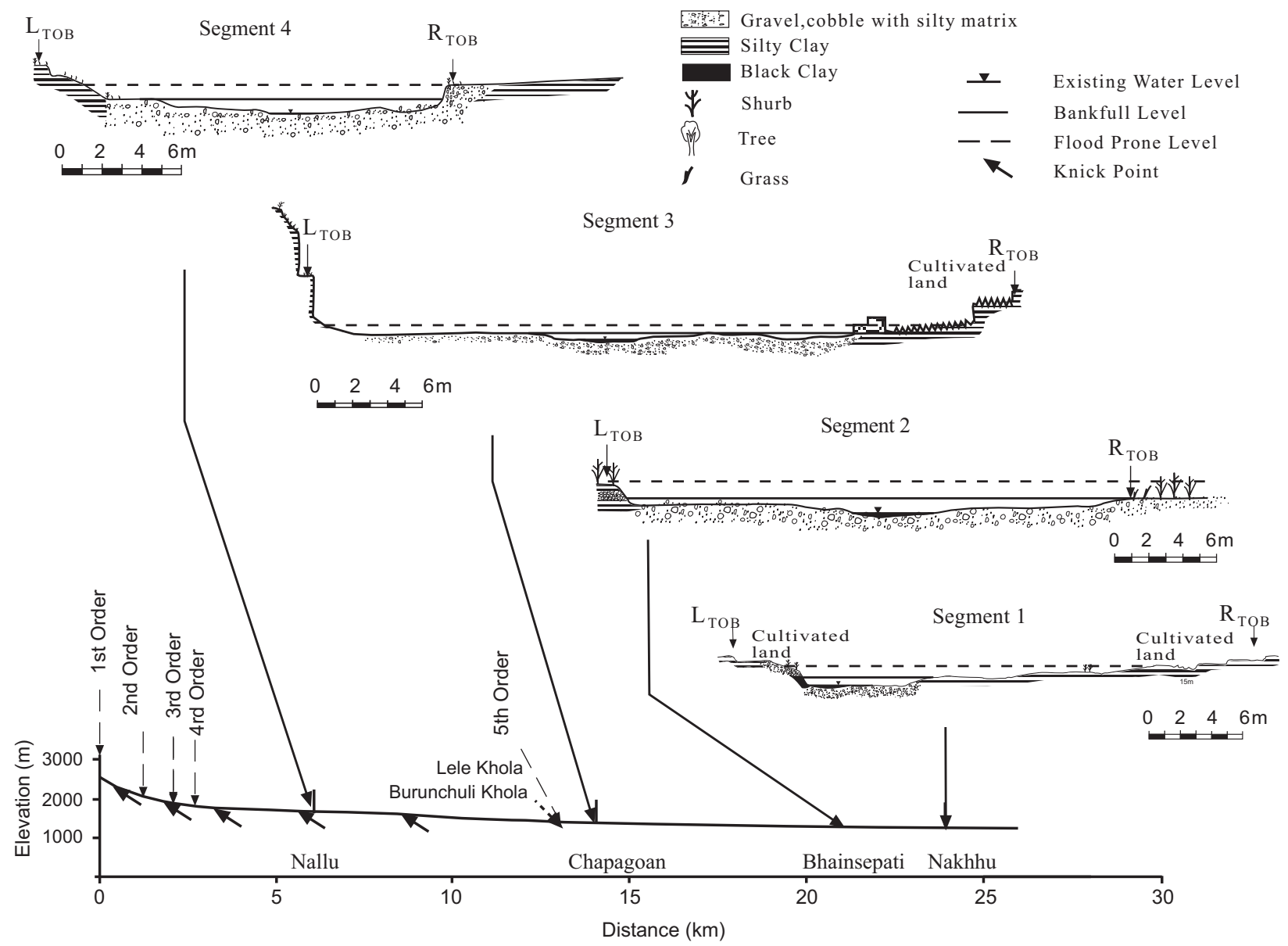

Fig. 3 Longitudinal Profile of the Nakhu River and cross-sections of its four segments 
Morpho-hydraulic parameters and existing stability condition of Nakhu River, southern Kathmandu, Central Nepal

Table 2: Results of Wolman pebble count on segments of the Nakhu River

\begin{tabular}{|c|c|c|c|c|c|c|c|c|c|c|c|c|c|c|c|}
\hline \multirow[b]{2}{*}{ Particle } & \multirow[b]{2}{*}{ Description } & \multicolumn{2}{|l|}{ Grainsize } & \multicolumn{3}{|c|}{$\begin{array}{c}\text { Segment } 1 \\
\text { (Nakhu) }\end{array}$} & \multicolumn{3}{|c|}{$\begin{array}{c}\text { Segment 2 } \\
\text { (Bhaisepati) }\end{array}$} & \multicolumn{3}{|c|}{$\frac{\text { Segment } 3}{\text { (Chapagoan) }}$} & \multicolumn{3}{|c|}{$\frac{\text { Segment } 4}{\text { (Nallu) }}$} \\
\hline & & $(\mathrm{mm})$ & $(\phi)$ & $\begin{array}{l}\text { Frequ- } \\
\text { ency } \\
\text { (f) }\end{array}$ & $\% \mathrm{f}$ & $\begin{array}{c}\text { Cum. } \\
\% f\end{array}$ & $\begin{array}{l}\text { Frequ- } \\
\text { ency } \\
\text { (f) }\end{array}$ & $\% \mathrm{f}$ & $\begin{array}{c}\text { Cum. } \\
\% \mathrm{f}\end{array}$ & $\begin{array}{l}\text { Frequ- } \\
\text { ency } \\
\text { (f) }\end{array}$ & $\% \mathrm{f}$ & Cum. \%f & $\begin{array}{l}\text { Frequ- } \\
\text { ency } \\
\text { (f) }\end{array}$ & $\% \mathrm{f}$ & $\begin{array}{c}\text { Cum. } \\
\% f\end{array}$ \\
\hline \multirow[t]{2}{*}{ Bed-rock } & & $>2048$ & -11 & & & & & & & 1 & 0.25 & 0.25 & 4 & 1 & 1 \\
\hline & Large & $1024-2048$ & -10 & & & & & & & & 0 & 0.25 & & 0 & 1 \\
\hline \multirow[t]{2}{*}{ Boulder } & Medium & $512-1024$ & -9 & & & & & & & & 0 & 0.25 & & 0 & 1 \\
\hline & Small & $256-512$ & -8 & & & & 1 & 0.25 & 0.25 & & 0 & 0.25 & 4 & 1 & 2 \\
\hline \multirow{2}{*}{ Cobble } & Large & $128-256$ & -7 & 5 & 1.25 & 1.25 & 9 & 2.25 & 2.5 & 10 & 2.5 & 2.75 & 15 & 3.75 & 5.75 \\
\hline & Small & $64-128$ & -6 & 21 & 5.25 & 6.5 & 33 & 8.25 & 10.75 & 49 & 12.25 & 15 & 70 & 17.5 & 23.25 \\
\hline \multirow{5}{*}{ Pebble } & Very coarse & $32-64$ & -5 & 43 & 10.75 & 17.25 & 35 & 8.75 & 19.5 & 65 & 16.25 & 31.25 & 69 & 17.25 & 40.5 \\
\hline & Coarse & $16.0-32$ & -4 & 51 & 12.75 & 30 & 44 & 11 & 30.5 & 63 & 15.75 & 47 & 32 & 8 & 48.5 \\
\hline & Medium & $8.0-16$ & -3 & 30 & 7.5 & 37.5 & 19 & 4.75 & 35.25 & 29 & 7.25 & 54.25 & 25 & 6.25 & 54.75 \\
\hline & Fine & $4.0-8$ & -2 & 16 & 4 & 41.5 & 12 & 3 & 38.25 & 4 & 1 & 55.25 & 2 & 0.5 & 55.25 \\
\hline & Very fine & $2.0-4$ & -1 & 12 & 3 & 44.5 & 5 & 1.25 & 39.5 & 3 & 0.75 & 56 & & 0 & 55.25 \\
\hline \multirow{5}{*}{ Sand } & Very coarse & $1.0-2.0$ & 0 & & 0 & 44.5 & & 0 & 39.5 & & 0 & 56 & & 0 & 55.25 \\
\hline & Coarse & $0.5-1.0$ & 1 & 7 & 1.75 & 46.25 & 12 & 3 & 42.5 & 9 & 2.25 & 58.25 & 19 & 4.75 & 60 \\
\hline & Medium & $0.25-0.5$ & 2 & & 0 & 46.25 & 8 & 2 & 44.5 & 6 & 1.5 & 59.75 & 6 & 1.5 & 61.5 \\
\hline & Fine & $0.125-0.25$ & 3 & & 0 & 46.25 & & 0 & 44.5 & 1 & 0.25 & 60 & 1 & 0.25 & 61.75 \\
\hline & Very fine & $0.063-0.125$ & 4 & & 0 & 46.25 & & 0 & 44.5 & & 0 & 60 & & 0 & 61.75 \\
\hline Silt/Clay & Silt/Clay & $<0.063$ & 5 & 215 & 53.75 & 100 & 222 & 55.5 & 100 & 160 & 40 & 100 & 153 & 38.25 & 100 \\
\hline
\end{tabular}

18.05 (Segment 3) to 34.4 (Segment 1). The downstream push of the channel is greater in segments 1, 2 and 4 compared to Segment 3. The meander belt width ratio (MWR) ranges from 14.91(Segment 1) to 25.50 (Segment 3) showing that the magnitude of meandering is large in the Segments 2 and 3 compared to Segments 1 and 4 .

\section{Longitudinal profile}

The longitudinal profile of the Nakhu River is concave upward (Fig. 3) with the average slope of $0.052 \mathrm{~m} / \mathrm{m}$. The slope of the lower order streams declines abruptly when the fourth order stream begins with a slope of $0.017 \mathrm{~m} / \mathrm{m}$. The slopes of the river from Segment 4 to Segment 1 gradually decrease from $0.017 \mathrm{~m} / \mathrm{m}$ to $0.012 \mathrm{~m} / \mathrm{m}$.

\section{Grain size distribution of riverbed material}

Wolman's (1954) pebble count was adopted to characterize riverbed material of individual segments. Ten transects in each segment were traversed for fourty counts. Fig. 4 represents probability plots from the frequency percent of clasts (Table 2). Based on median size, the sediments of Segments 1 and 2 are very fine sands, and those of segments 3 and 4 are pebble-grade bed material. The size distribution of Segment 1 is very poorly sorted and of segments
2, 3 and 4 are extremely poorly sorted (Table 3 ). Segment 3 indicates five sub-populations whereas other segments represent four sub-population. Fine sand to pebble grade material are relatively poorly sorted than very fine sand and cobble grade materials. In all the segments, pebble-cobble and mud are the dominant bed materials.

\section{STREAM CLASSIFICATION}

Morphological characteristics (Rosgen, 1994) viz ER, W/D ratio, $K$, slope and bed material were adopted for the classification of the stream. Segments 1, 2, 3 and 4 are classified as C5-, C5-, C4- and C4stream, respectively (Table 3 ).

Table 3: Summary of classification of the Nakhu River

\begin{tabular}{|c|c|c|c|c|}
\hline Attribute & gment 1 & egment 2 & segment 3 & segment 4 \\
\hline Entrenchment ratio, E/R & 3.05 & 4.00 & 2.52 & 3.37 \\
\hline $\mathrm{W} / \mathrm{D}$ ratio & 30.19 & 39.94 & 90.79 & 31.26 \\
\hline Sinuosity, K (m/m) & 1.17 & 1.52 & 1.19 & 1.25 \\
\hline Slope $(\mathrm{m} / \mathrm{m})$ & 0.012 & 0.013 & 0.015 & 0.017 \\
\hline Bed material, $\mathrm{D}_{50}(\mathrm{~mm})$ & 0.12 & 0.12 & 24.25 & 28.84 \\
\hline Sorting, $\sigma_{\mathrm{I}}(\phi)$ & 3.96 & 4.08 & 4.23 & 4.34 \\
\hline Rosgen stream type & $\mathrm{C} 5$ & $\mathrm{C} 5$ & $\mathrm{C} 4$ & $\mathrm{C} 4$ \\
\hline
\end{tabular}



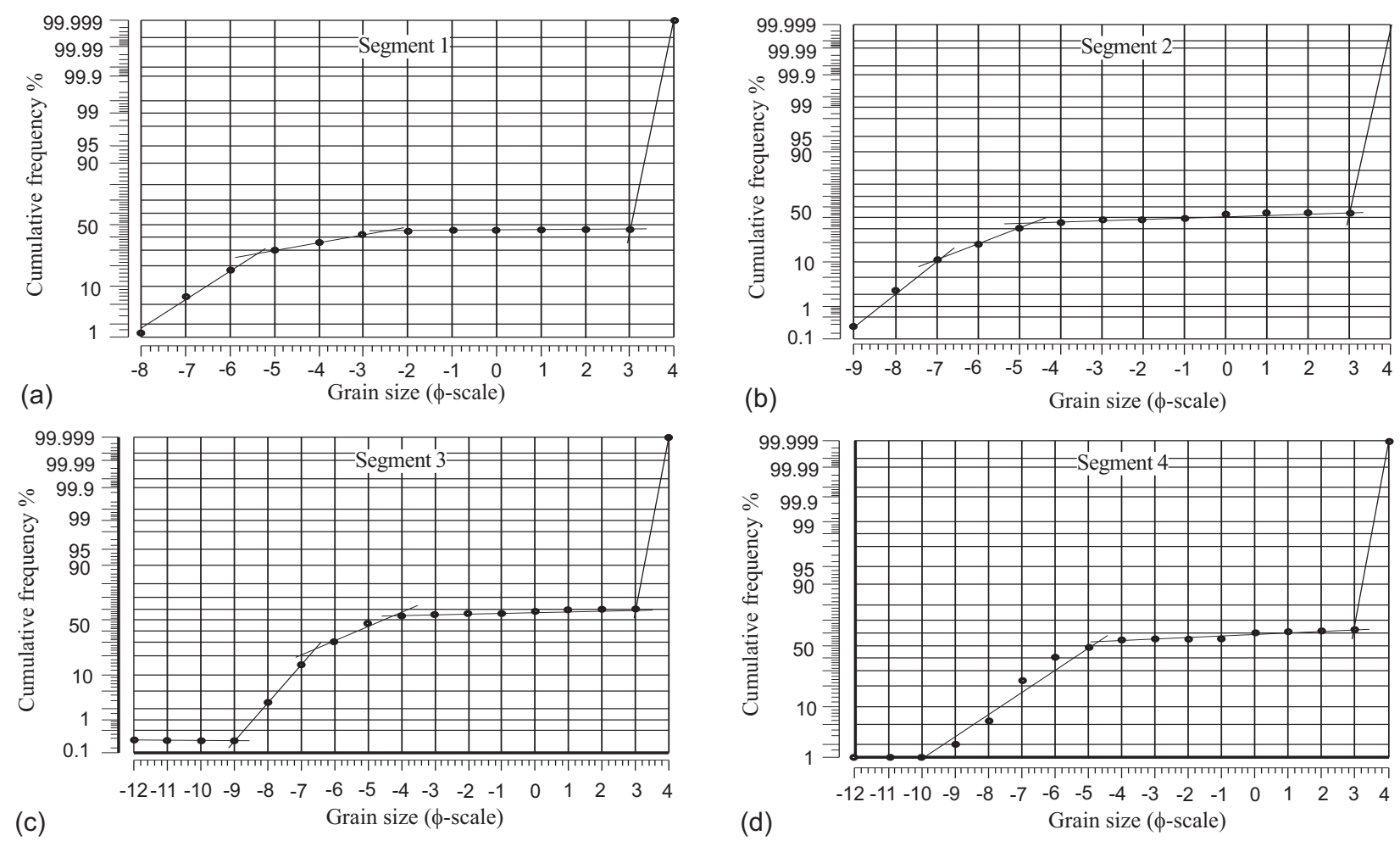

Fig. 4 Grain size distribution of Nakhu River: (a) Segment 1; Nakhu, (b) Segment 2; Bhainsepati, (c) Segment 3; Chapagaon, and (d) Segment 4; Nallu

\section{C5-stream type}

Segment 1 is less entrenched $(>1.4)$ with high W/D ratio (30.19) and low sinuosity $(\mathrm{K}=1.17)$ with bed material of gravel and silt/clay mixture with little sand. Point bars, point bars with a few mid channel bars and side bars characterize the deposition pattern of this stream. Riparian vegetation along the river corridor is poor, and constitutes mainly shrub and grass, and minorly few trees (Fig.

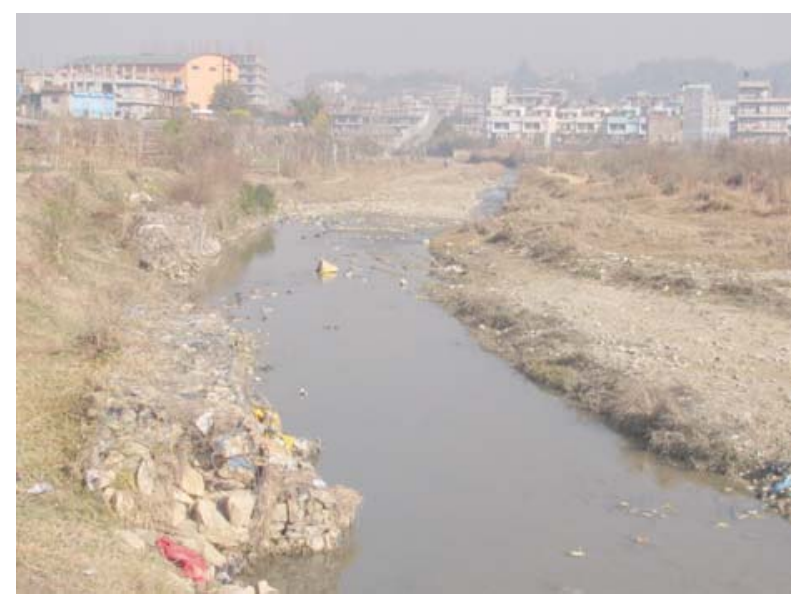

Fig. 5 Downstream view of the segment 1 at Nakhu
5). Most of the reaches of the corridor are accompanied by cultivated and built-up areas. The river segment has been affected by clearing of the riparian vegetation, bank encroachment, extremely high effluent discharge from settlement areas, and encroachment of river banks for extending roads.

Segment 2 has a broad valley with terraces associated with well defined flood plains. Segment 2 is slightly entrenched $(E R=4.0)$ with well defined

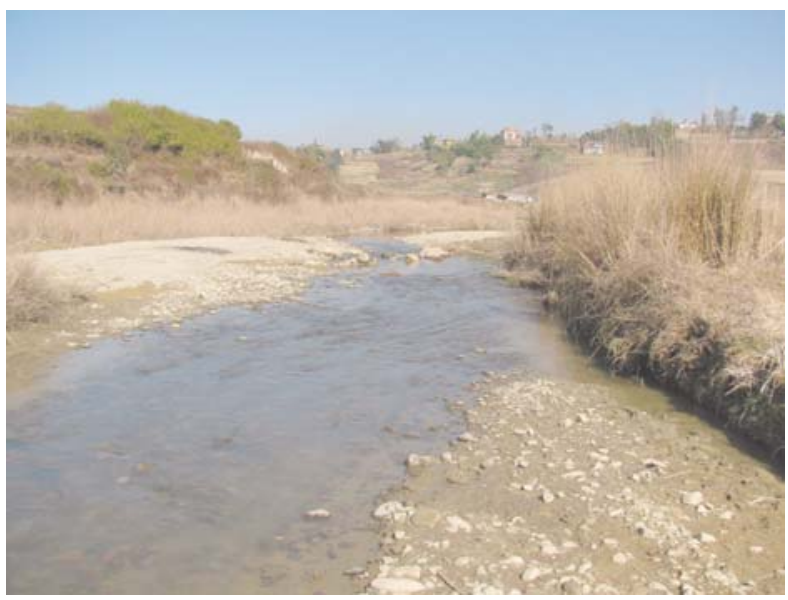

Fig. 6 Downstream view of the segment 2 at Bhainsepati 


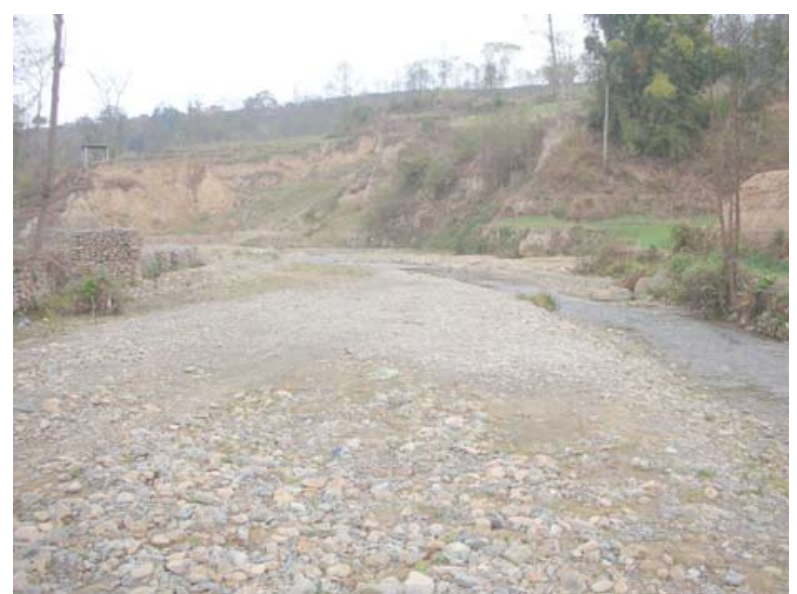

Fig. 7 Downstream view of the segment 3 of the Nakhu River at Chapagaon area

meandering channel $(\mathrm{K}=1.52)$, high $\mathrm{W} / \mathrm{D}$ ratio (39.94), and low gradient $(<0.02 \mathrm{~m} / \mathrm{m})$. The bed material comprises fine sand with gravel. Deposition pattern in the stream is characterized by abundant channel bars and point bars. Riparian vegetation is represented by grass, shrubs. Distribution of tree is only in certain part in patchy and discontinuous pattern (Fig. 6). The banks exhibit erosional scarps. Seasonal channel shifting is remarkable. Building of gabion walls, cultivation of banks, grazing, bank encroachment and riparian vegetation clearing are major problems.

\section{C4-Stream type}

Segment 3 and 4 are slightly entrenched with W/D ratio greater than 12 (Table 2). These are well defined meandering channel with low sinuosity generally less than 1.5 ( $\mathrm{K}$ of segment $3=1.19$ and $\mathrm{K}$ of segment $4=1.25$ ) with very gentle slopes. Both segments have broad valleys with terraces in association with flood plains. The bed materials are composed of fine gravel. Abundant point bars and mid-channel bars constitute depositional channel elements. Riparian vegetation is represented by grasses, shrubs, and linear to patchy isolated trees (Fig. 7 and 8). Segment 3 has few trees in a discontinuous pattern in few parts of the segment with wide flood plains. The banks exhibit erosional scarps and a few landslides. Segment 4 exhibits better condition than others. Seasonal channel shifting is quite remarkable in segment 3. Excavation of gravel from channels, cultivation on the banks

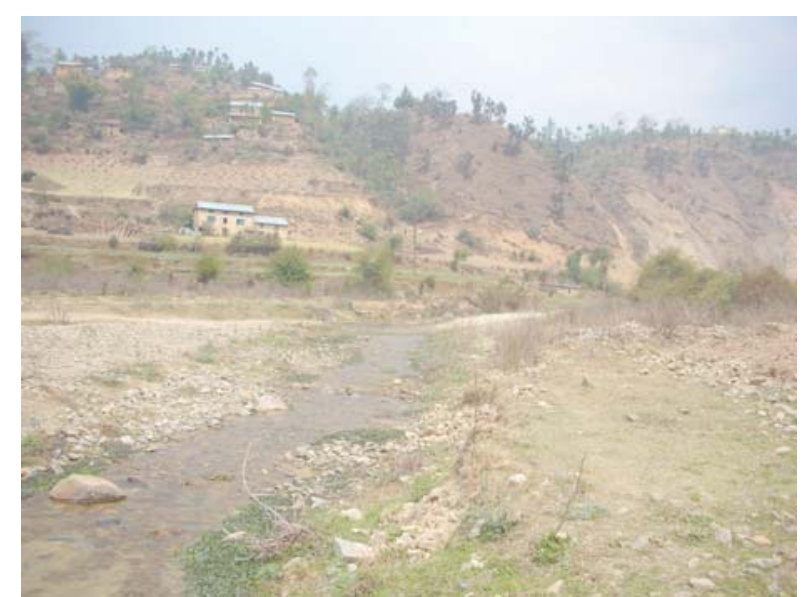

Fig. 8 Downstream view of the segment 4 of the Nakhu River at Nallu area

and bars, and grazing activities are the major disturbances which have been impairing the river segments.

\section{HYDRAULIC PARAMETERS}

Table 4 lists hydraulic parameters of the Nakhu River segments. The Manning's roughness coefficients of segments 1, 2, 3 and 4 are respectively, $0.090,0.125,0.121$, and 0.144 . The higher values are mainly due to channel irregularities, high sinuosity, large riverbed sediment size and notable instream vegetation.

The bankfull discharge and velocity after Manning's equation and continuity equation, respectively, are defined as:

$$
\begin{aligned}
& \mathrm{Q}=\left(\mathrm{A} \mathrm{R}^{2 / 3} \mathrm{~S}^{1 / 2}\right) / \mathrm{n} \\
& \mathrm{V}=\mathrm{Q} / \mathrm{A}
\end{aligned}
$$

where, $\mathrm{A}=$ bankfull cross-sectional area, $\mathrm{R}=$ hydraulic radius, $\mathrm{n}=$ Manning's roughness coefficient, $\mathrm{V}=$ velocity and $\mathrm{Q}=$ discharge .

The bankfull discharge ranged from $2.970 \mathrm{~m}^{3} / \mathrm{s}$ for Segment 4 to $10.236 \mathrm{~m}^{3} / \mathrm{s}$ for Segment 1. The bankfull velocities were also the least for Segment $4(0.511 \mathrm{~m} / \mathrm{s})$ and greatest for Segment $1(0.881$ $\mathrm{m} / \mathrm{s})$.

\section{STABILITY CONDITION}

Stability condition of a river is explained by behaviour of the river towards lateral and vertical 
Table 4: Results of hydraulic parameters of the Nakhu River segments

\begin{tabular}{lcccc}
\hline \multicolumn{1}{c}{ Attribute } & Segment 1 & Segment 2 & Segment 3 & Segment 4 \\
\hline Width at bankfull, $\mathrm{W}_{\text {bkf }}(\mathrm{m})$ & 17.64 & 17.82 & 19.53 & 12.88 \\
Bankfull x-section area, $\mathrm{A}_{\text {bkf }}\left(\mathrm{m}^{2}\right)$ & 11.62 & 8.39 & 9.20 & 5.82 \\
Mean depth at bankfull, $\mathrm{D}_{\text {bkf }}=\mathrm{A}_{\text {bkf }} / \mathrm{W}_{\text {bkf }}(\mathrm{m})$ & 0.62 & 0.44 & 0.44 & 0.42 \\
Wetted perimeter $(\mathrm{m})$ & 18.88 & 18.71 & 20.41 & 13.73 \\
Hydraulic radius $(\mathrm{m})$ & 0.62 & 0.45 & 0.45 & 0.42 \\
Slope $(\mathrm{m} / \mathrm{m})$ & 0.012 & 0.013 & 0.015 & 0.017 \\
Manning's roughness coffcient, $\mathrm{n}$ & 0.090 & 0.125 & 0.121 & 0.144 \\
Bankfull discharge $\mathrm{Q}\left(\mathrm{m}^{3} / \mathrm{s}\right)$ & 10.236 & 4.478 & 5.473 & 2.970 \\
Bankfull Velocity, $\mathrm{V}(\mathrm{m} / \mathrm{s})$ & 0.881 & 0.534 & 0.595 & 0.511 \\
\hline
\end{tabular}

components due to tendency of erosion. The overall behavior is exhibited by whether the river is potentially aggrading or degrading, and the competency of the river to entrain and transport the coarse sediments.

\section{Vertical stability}

Bank height Ratio (BHR) and Entrenchment Ratio (ER) are two parameters which are indicators of vertical stability of channels. BHR shows a degree of incision which river had undergone relative to its depth, whereas ER shows a degree of incision taken place compared to its flood prone width. As BHR exceeds 1.5 for all the segments, they are vertically unstable to some extent. The segment 3 possesses higher degree of vertical instability compared to the rest of the segments which have approximately the same degree of instability (Table 1). All the segments are notably not entrenched at present condition.

\section{Lateral stability}

The Nakhu River segments are laterally unstable because they bear high Meandering Width Ratio (MWR), and show tendency of shifting of the river belt. W/D ratio of all the segments are notably high and that of segment 3 even exceeds 40 and is more vulnerable to lateral shifting of the channel due to expansion of width of the channel by erosion.

\section{Competence}

Shields (1936) equation was used for boundary shear stress:

$$
\tau=\gamma \mathrm{RS}
$$

where, $\tau$ is boundary shear stress, $\gamma$ is density of water, $\mathrm{R}$ is hydraulic radius and $\mathrm{S}$ is channel slope. The boundary shear stress varies between 5.827 $\mathrm{N} / \mathrm{m}^{2}$ to $7.386 \mathrm{~N} / \mathrm{m}^{2}$ (Table 5).

Dimensionless shear stresses were derived after equation of Andrew (1983):

$$
\tau^{*}{ }_{\mathrm{ci}}=0.0834\left(\mathrm{~d}_{\mathrm{i}} / \mathrm{d}_{\mathrm{s} 50}\right)^{-0.872}
$$

where, $\tau^{*}{ }_{\mathrm{ci}}$ is a critical dimensionless shear stress needed to entrain $d_{i}$ (coarsest 10th percentile) of the riverbed material and $\mathrm{d}_{\mathrm{s} 50}$ is a median diameter of a bar material.

Then the critical depth and critical slope required to mobilise the $d_{i}$ particles of bed were obtained as:

$$
\begin{aligned}
& \mathrm{D}_{\mathrm{c}}=\left(1.65 \tau^{*}{ }_{\mathrm{ci}} \mathrm{d}_{\mathrm{i}}\right) / \mathrm{S} \\
& \mathrm{S}_{\mathrm{c}}=\left(1.65 \tau{ }^{*}{ }_{\mathrm{ci}} \mathrm{d}_{\mathrm{i}}\right) / \mathrm{D}
\end{aligned}
$$

where, $\mathrm{D}$ is the existing depth at bankfull and $\mathrm{S}$ is the existing slope.

The critical dimensionless shear stress, which is required to initiate movement of the coarsest 10th percentile of the riverbed material, ranges from 0.012 (Segment 3) to 0.025 (Segment 2). The critical depth $\left(D_{c}\right)$ and critical slope $\left(S_{c}\right)$ required to mobilise the coarsest 10th percentile fraction would be the half of those of the existing depth and slope of the channel (except for segment 2), indicating that the Nakhu River segments are competent enough to mobilise the riverbed materials currently distributed in the river. The segment 2 has almost the critical depth and slope equal to the existing depth and slope still showing that the segment is competent.

\section{Aggrading/degrading potential}

The following relationship of Schumm (1963) was used to evaluate aggrading/degrading potential: 
Table 5: Results of calculation of shear stress, F-factor and M-factor

\begin{tabular}{lcccc}
\hline Parameters & Segment 1 & Segment 2 & Segment 3 & Segment 4 \\
\hline $\mathrm{d}_{50}(\mathrm{~m})$ & 0.00012 & 0.00012 & 0.02425 & 0.02884 \\
$\mathrm{~d}_{\mathrm{s} 50}(\mathrm{~m})$ & 0.020420 & 0.034070 & 0.017430 & 0.024415 \\
$\mathrm{~d}_{10}(\mathrm{~m})$ & 0.094 & 0.135 & 0.155 & 0.201 \\
$\mathrm{~d}_{10} / \mathrm{d}_{\mathrm{s} 50}$ & 4.601 & 3.971 & 8.917 & 8.228 \\
$\tau\left(\mathrm{N} / \mathrm{m}^{2}\right)$ & 7.386 & 5.827 & 6.761 & 7.200 \\
$\tau_{\mathrm{cr}}$ & 0.022 & 0.025 & 0.012 & 0.013 \\
$\mathrm{D}_{\mathrm{c}}$ & 0.285 & 0.430 & 0.212 & 0.259 \\
$\mathrm{~S}_{\mathrm{c}}$ & 0.005 & 0.013 & 0.007 & 0.010 \\
$\mathrm{~F}-$ factor $=W / D$ ratio & 28.350 & 40.047 & 44.386 & 30.324 \\
M-factor & 50.464 & 52.952 & 36.645 & 37.609 \\
\hline
\end{tabular}

$$
\mathrm{F}=255 \mathrm{M}^{-1.08}
$$

where, $\mathrm{F}$ and $\mathrm{M}$ are defined as:

$$
\begin{gathered}
\mathrm{F}=\mathrm{W}_{\mathrm{bkf}} / \mathrm{D}_{\mathrm{bkf}} \\
\mathrm{M}=\left[\left(\mathrm{S}_{\mathrm{r}} \cdot \mathrm{W}_{\mathrm{bkf}}\right)+\left(\mathrm{S}_{\mathrm{b}} \cdot 2 \mathrm{D}_{\mathrm{bkf}}\right)\right] /\left(\mathrm{W}_{\mathrm{bkf}}+2 \mathrm{D}_{\mathrm{bkf}}\right)
\end{gathered}
$$

where, $S_{r}$ is percentage of silt and clay in wetted perimeter of a riffle cross-section and $\mathrm{S}_{\mathrm{b}}$ is percentage of silt and clay in a bar material.

Fig. 10 shows the $\mathrm{F}$ versus $\mathrm{M}$ relationship. The plots of all the four segments of the Nakhu River lie on the aggrading field of this diagram.

\section{DISCUSSIONS}

The four segments which have been surveyed indicate that they are moderately entrenched. The fifth order segments of the Nakhu River are relatively more entrenched than those of the Manahara River, but the fifth and sixth order segments of the Bishnumati River are even more entrenched (Table 6). Among the three rivers, W/D ratio of the Nakhu River is intermediate between high ratios of the Manahara River and the low of the Bishnumati River. Sinuousity, is highly variable, but the fourth order segment of the Nakhu River shows the least sinuosity. Remarkably, radius of curvature of the Nakhu River is highest among the rivers. Considering the slope, the fifth order segment of the Nakhu River shows the highest slopes among the rivers. The meander length and meander belt width of the Nakhu River exhibit low range while that of the Manahara and the Bishnumati Rivers show wide range. Considering $\mathrm{D}_{50}$ of the fifth order segments, all lie in sand-grade except for the upstream segment of the Nakhu River. In the latter, $\mathrm{D}_{50}$ of the fourth order segments is the coarsest because of existence of debris flow events and derivation of large sized gravel in this river. The variability of the above parameters among the rivers is attributed to river dynamics of the individual basin and supply of sediments from the source rocks. Compared to the Bishnumati and the Manahara River, the Nakhu River is more capable of carrying huge volume of sediments considering its competency. The fourth (Segment 4) and fifth (Segments 1, 2 and 3) order segments of this river are aggrading in nature.

\section{CONCLUSIONS}

The Nakhu River is the fifth order main-stem river draining the watershed, and the latter is characterized by dendritic and parallel drainage patterns. The drainage texture ranges from very coarse in the northern part where relative relief is low, and fine to moderately fine in the southern part where relative relief is high.

Grain size distributions of stream segments indicate that the $d_{50}$ of the river bed sediments of segments 1, 2, 3 and 4 are respectively, $0.120 \mathrm{~mm}$, $0.122 \mathrm{~mm}, 24.25 \mathrm{~mm}$ and $28.84 \mathrm{~mm}$. Segments $1,2,3$ and 4 of the Nakhu River is classified as C5-, C5-, C4- and C4-stream types, respectively. C5-stream is characterized by less entrenched meandering channel on low gradients with high W/D ratio and fine sand with gravel in the channel. C5- and C4-

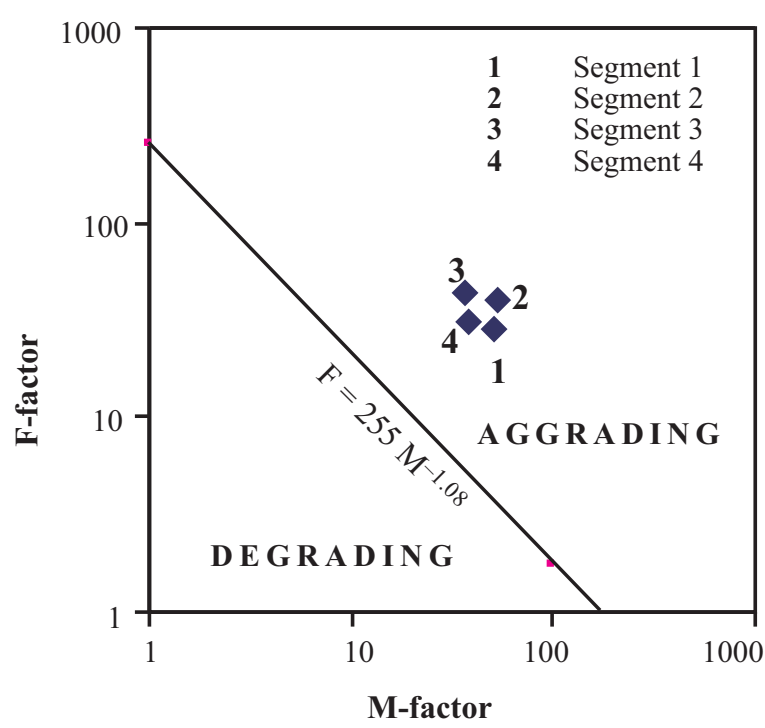

Fig. $10 \mathrm{~F}$ versus $\mathrm{M}$-factor diagram showing aggrading/degrading potential of the Nakhu River segments 
Table 4: Summary of classification of the Nakhu River

\begin{tabular}{|c|c|c|c|}
\hline Attribute & & $\begin{array}{l}\text { 5th order } \\
\text { stream }\end{array}$ & $\begin{array}{l}\text { 4th order } \\
\text { stream }\end{array}$ \\
\hline \multirow{3}{*}{$\begin{array}{l}\text { Entrenchment ratio, } \\
\text { E/R }\end{array}$} & *Bishnumati River & 1.37 & 4.78 \\
\hline & **Manahara River & $1.39-12.22$ & 1.43 \\
\hline & Nakhu River & $2.52-14.00$ & 3.37 \\
\hline \multirow[t]{3}{*}{$\mathrm{W} / \mathrm{D}$ ratio } & Bishnumati River & 26 & 12 \\
\hline & Manahara River & $66-85$ & 48 \\
\hline & Nakhu River & $28-44$ & 30 \\
\hline \multirow[t]{3}{*}{ Sinuosity, K (m/m) } & Bishnumati River & 1.16 & 1.34 \\
\hline & Manahara River & $1.14-2.11$ & 1.43 \\
\hline & Nakhu River & $1.17-1.52$ & 1.25 \\
\hline \multirow{3}{*}{$\begin{array}{l}\text { Radius of } \\
\text { curvature, Rc }\end{array}$} & Bishnumati River & 51 & 89 \\
\hline & Manahara River & $103-125$ & 98 \\
\hline & Nakhu River & 138-202 & 107 \\
\hline \multirow[t]{3}{*}{ Slope $(\mathrm{m} / \mathrm{m})$} & Bishnumati River & 0.004 & 0.008 \\
\hline & Manahara River & $.006-0.024$ & 0.030 \\
\hline & Nakhu River & $0.012-0.015$ & 0.017 \\
\hline \multirow{3}{*}{$\begin{array}{l}\text { Bed material, } \\
\text { D50 }(\mathrm{mm})\end{array}$} & Bishnumati River & 0.874 & 3.73 \\
\hline & Manahara River & $2.00-3.00$ & 12.00 \\
\hline & Nakhu River & $0.121-24.25$ & 28.84 \\
\hline \multirow{3}{*}{$\begin{array}{l}\text { Meander } \\
\text { length, Lm } \\
\text { (m) }\end{array}$} & Bishnumati River & 235 & 100 \\
\hline & Manahara River & $450-760$ & 400 \\
\hline & Nakhu River & $460-607$ & 400 \\
\hline \multirow{3}{*}{$\begin{array}{l}\text { Meander belt } \\
\text { width, } \mathrm{W}_{\text {blt }} \\
\text { (m) }\end{array}$} & Bishnumati River & 160 & 540 \\
\hline & Manahara River & $160-670$ & 210 \\
\hline & Nakhu River & $255-356$ & 211 \\
\hline \multirow[t]{3}{*}{ Rosgen stream type } & Bishnumati River & F5 & $\mathrm{C} 4$ \\
\hline & Manahara River & $\mathrm{F} 4, \mathrm{C} 4, \mathrm{C} 4$ & B4 \\
\hline & Nakhu River & $\mathrm{C} 5, \mathrm{C} 4$ & $\mathrm{C} 4$ \\
\hline
\end{tabular}

stream types are characterized by broad valleys with terraces associated with flood plains and slightly entrenched segments with well defined meandering channels.

The Nakhu River segments are all competent enough to mobilise their sediments present on channel and bars during the bankfull flows. During the high magnitude flood, even larger clasts of boulder sized may be mobilised. All the river segments fall in aggrading categories showing that the river is not only capable of mobilising the sediments but also capable of depositing its load effectively.

At present, the natural condition of the Nakhu River has been pervasively impaired due to human influence, e.g., quarrying of bedrocks, human settlements and extension of road alignment. In segment 4 , it is due to mining activities, whereas in other segments, human settlements and their lifestyles have impacted morphological and dynamic function of the river. Tendency of morphological changes in C5-stream is pronounced due to recently built-up road alignment along the right bank of the Nakhu River. To improve the river function, futher studies and river rehabilitation works are required.

\section{REFERENCES}

DMG, 1998, Engineering and Environmental Geological Map of Kathmandu Valley, Department of Mines and Geology, Lainchaur, Kathmandu.

Leopold, L.B., Wolman, M.G. and Miller, J.P., 1964. Fluvial processes in geomorphology. W. H. Freeman \& Co., San Fransisco, U.S.A., 522p.

Rosgen, D.L., 1994. A classification of natural rivers, Cantenna, V. 22, pp. 169-199.

Rosgen, D.L., 1996, Applied River Morphology, Wildland Hydrology, Pasoga, Spring, Colorodo, 390p.

Sakai, H., 2001. The Kathmandu Basin: an archive of Himalayan uplift and past monsoon climate. Jour. Nepal. Geol. Soc., Special Issue, v. 25, pp. 1-8.

Schumm, S.A., 1963. A tantative classivication system of alluvial rivers. Circular 477, U.S. Geological survey, Washington, D.C.

Shrestha, P. and Tamrakar, N.K., 2007. Streambank erodibility and lateral instability hazard in the Manahara River, Kathmandu basin, Nepal, Jour. Nepal Geol. Soc., v. 35, pp. 55-66.

Stöcklin, J. \& Bhattarai, K.D. (1977), Geology of Kathmandu area and central Mahabharat range, Nepal Himalaya: A Report of Department Mines and Geology/ UNDP (Unpublished).

Stöcklin, J. (1981), Geology of Kathmandu area and central Mahabharat range, Nepal Himalaya, HMGUNDP, Mineral exploration project, Kathmandu Nepal.

Tamrakar, N.K., 2004, Disturbances and Instabilities in the Bishnumati River Corridor, Kathmandu Basin. The JUSAN (Japan University Students Association Nepal), v. 9, issue 16, pp. 7-18.

Tamrakar, N.K and Bajracharya, R., 2009, Fluvial Environment and Existing Stability Condition of the Manahara River, Central Nepal, Journal of Nepal Geological Society, v. 39, (Press).

Wolman, M.G., 1954, A method of sampling coarse riverbed material. Trans. Am. Geophys. Union, v. 35, pp. 